\title{
Prospective study of treatment outcome in chronic suppurative otitis media (Attico - antral Disease)
}

\author{
Ganesh Bala Arivazhagan', Sriram Govindaraj², Ganesh Babu ${ }^{3}$, Harishvel V ${ }^{4}$ \\ ${ }^{1}$ Dr. Ganesh Bala Arivazhagan, Associate Professor, ${ }^{2}$ Dr. Sriram Govindaraj, Assistant Professor, ${ }^{3}$ Dr. Ganesh Babu, \\ Postgraduate, ${ }^{4}$ Dr. Harishvel V, Postgraduate, all authors are affiliated with Department of Otorhinolaryngology, \\ Vinayaka Mission's Medical College, Vinayaka Mission Research Foundation- DU, Keezhakasakudi, Karaikal, \\ Puducherry, India.
}

Corresponding Author: Dr. Ganesh Bala Arivazhagan, Department of Otorhinolaryngology, Vinayaka Mission's Medical College, Vinayaka Mission Research Foundation-DU, Keezhakasakudi, Karaikal, Puducherry, India. E-mail: gbala.mbbs@gmail.com

\begin{abstract}
Aim: To analyse the post operative outcome in patients with CSOM - Atticoantral type and compare the outcomes in terms of disease clearance and improvement in hearing. Material and Methods: 50 Patients who were diagnosed as Chronic Suppurative otitis Media of Attico-antral type, detailed history \& clinical examination and investigations were performed. Per-operative findings (status of ossicles, middle ear, antrum, mastoid), Post operative follow up (1, 3 and 6 months)- disease clearance and hearing status was done. Results: Out of total 50 patients, Canal Wall Down Procedures (Modified radical mastoidectomy with Tympanoplasty) had a good success rate in disease clearance when compared with Canal Wall Up Procedures (Cortical Mastoidectomy/ Atticotomy With Tympanoplasty). Irrespective of canal wall up (or) canal wall down procedures, Type II Tympanoplasty show better results of hearing improvement when compared to other surgical procedures. Conclusion: In our study, postoperative surgical outcome were statistically analyzed using Chi square test, in which Canal wall down procedures showed good result in terms of disease clearance and Type II tympanoplasty showed good result in terms of hearing improvement.
\end{abstract}

Keywords: Attico-antral disease, Chronic Suppurative Otitis Media (CSOM), Conductive Hearing Loss (CHL), Canal Wall Up Procedures, Canal Wall Down Procedures, Tympanoplasty

\section{Introduction}

Chronic Suppurative Otitis Media (CSOM) defined as inflammation of the middle ear cleft [1]. The chronic discharging ear is still one of the common problems that the Otorhinolaryngologist in India and other developing countries are encountering. Although, thanks to the advent of newer antibiotics, the incidence of acute suppurative otitis media and its complications have reduced, chronic suppurative otitis media and their complications are still prevalent.

The continuation of the infection and the bone eroding properties of granulation tissue and cholesteatoma seen in CSOM are known to be the major pathological process causing these complications. As there is no simple means to eradicate this chronic pathology, appropriate and timely intervention by an otologist goes

Manuscript received: $10^{\text {th }}$ January 2019

Reviewed: $20^{\text {th }}$ January 2019

Author Corrected: $28^{\text {th }}$ January 2019

Accepted for Publication: $2^{\text {nd }}$ February 2019 a long way in the prevention of these human maladies. In cases of chronic suppurative otitis media with atticoantral pathology, treatment modality is only surgery. Surgical options available are the canal wall down mastoidectomy and intact canal wall mastoidectomy.

Austin DF et al reported that rate of recurrence of cholesteatoma was $4 \%$ for the Canal wall down technique and $39 \%$ in intact canal wall technique[2]. Dodson EE et al reported patients who undergone intact canal wall technique for treatment of cholesteatoma shows better hearing results post operatively compared to canal wall down technique[3].

The choice of technique is controversial and it is dependent on several factors, including extent of disease. Sheeley et al proposed two-stagesurgery as the first stage was disease eradication and membrane repair with silastic elastomer and the second stage of tympanic 
exploration and ossicular reconstruction, 6-12 months later [4]. Prior to the mid-1950s, the treatment for unsafe ear was accomplished by removal of the posterior external auditory canal wall, resulting in a radical or modified radical mastoidectomy cavity. The past 50 years have witnessed a trend away from mandatory canal wall removal.

Many otologic surgeons now prefer intact canal wall mastoidectomy with tympanoplasty except when canal wall removal is required because of extensive disease, inadequate access for cholesteatoma excision, operation on an "only hearing ear," or uncertainty of adequate followup. Portmann et al, cut the posterior canal wall bone of the external canal after skeletonization of the mastoid and repositioned the bone after complete resection of the disease[5].

Tarabichi $\mathrm{M}$ et al stated that the endoscopic technique allows for transcanal, minimally invasive, eradication of limited cholesteatoma. Preservation of the ossicles coupled with complete removal of disease is more likely with the endoscope. Continuous post-operative office based endoscopic surveillance is critical to the success of this approach[6].

The popularity of intact canal wall mastoidectomy stems from the benefits of maintaining a canal wall, which include freedom from the need for frequent mastoid bowl cleanings, freedom from water intolerance and calorically induced vertigo, and less difficulty in fitting and use of hearing aids. Kim JH et al (2009) reported in attic cholesteatoma, if the mass is removed by attico-antrotomy and the attic is obliterated or reconstructed with cartilage, the rates of recurrence can be decreased.

Attic reconstruction with cartilage could improve the hearing post-operatively, while attic obliteration could not. Thus attico-antrotomy is a relatively effective procedures that can be used in the management of cholesteatoma extending from the attic[7].

Kapur TR et al detected 26.5\% failures (recurrence), $47.5 \%$ of which were due to attic retraction pocket, and $10 \%$ of which are due to residual cholesteatoma. The cholesteatoma recurrence rate in their patients with less than 10 years of follow up was $8.8 \%$, significantly lower than the rate in patients with more than 10 years of follow up[8].

The present study has been carried out to provide an idea to the treating surgeon in choosing the appropriate surgical procedure for chronic suppurative otitis media -attico antral disease in terms of disease clearance and hearing improvement.

\section{Aims and Objectives}

To analyse the pre- operative findings and postoperative outcome in patients with CSOM

Atticoantral type and compare the outcomes in terms of disease clearance and improvement in hearing.

\section{Methodology}

Place of Study: Department of Otorhinolaryngology, Vinayaka Mission Medical College \& Hospital, Karaikal

Type of Study: Prospective Study

Sample Collection: 50 Patients diagnosed as Chronic Suppurative Otitis Media of Attico-antral type

Inclusion Criteria: CSOM - Attico-antral type, Complications of CSOM and all age groups

Exclusion Criteria: CSOM- Tubo-tympanic type, Systemic Illness, Previous Ear Surgeries and Congenital Ear Malformations

Statistical Methods: Statistically analyzed usingChi square test. $\mathrm{P}$ value $<0.05$ was taken as significant

Surgical procedure:Canal Wall Up Mastoidectomy with tympanoplasty, Canal Wall Down Mastoidectomy with tympanoplasty

This prospective clinical study was conducted in Department of Otorhinolaryngology, Vinayaka Mission Medical College \& Hospital, Karaikal for a period of 2 years from September 2016 to September 2018.

After getting ethical committee clearance, 50 Patients who were diagnosed as Chronic Suppurative Otitis Media of Attico-antral type, detailed history \& clinical examination were performed.

Inclusion criteria are CSOM Attico-antral type, Complications of CSOM, All age groups.

Exclusion criteria are CSOM- Tubo- tympanic type, Systemic Illness, Previous Ear Surgeries, Congenital Ear Malformations. A detailed proforma was filled from each patients with regard to his history, complete general physical, systemic and ENT examination. In all 


\section{Original Research Article}

patients routine blood investigation, Preoperative otoscopic/ otomicroscopic findings, Tuning fork test, Pure tone Audiometry, Plain X-ray Both Mastoid (Law's view), HRCT Scan - Temporal Bone, Culture \& Sensitivity,

Per-operative findings (status of ossicles, middle ear, antrum, mastoid), Post operative follow up (1, 3 and 6 months)- disease clearance and hearing status was done. Statistically analyzed using Chi square test.P value $<0.05$ was taken as significant.

Anesthesia- Patients were operated under General Anaesthesia. Local infiltrationwith 2\% lidocaine with epinephrine (1 in 50,000) was used to achieve haemostasis during surgical procedures[9].

Surgical Procedures- 1) Patients with Postero-Superior Retraction Pocket \& limited cholesteatoma were taken up for Canal Wall Up procedures (Cortical Mastoidectomy, Atticotomy \& Atticoantrostomy) with
Tympanoplasty. 2) Patients with Extensive Cholesteatoma \& Cholesteatoma with complications were taken up for Canal Wall Down procedures (Modified Radical Mastoidectomy) with Tympanoplasty.

According to Wullstein's classification, Type I, Type II or Type III tympanoplasty was done for intact canal wall mastoidectomy and Type II, Type III or Type IV tympanoplasty was done for canal wall down mastoidectomy.

Post- Operative Management- Patients were started on suitable antibiotics. Antibiotics were given for one week along with Analgesics, Antihistamine.

Mastoid bandage was changed on the $2^{\text {nd }}$ post operative day \& dressings applied. The sutures are removed on the $7^{\text {th }}$ post operative day. Patients are reviewed 2 weeks after discharge $\&$ consecutive review on $1^{\text {st }}, 3^{\text {rd }}$ and $6^{\text {th }}$ month post operatively.

\section{Results}

Table-1:Operative Procedures \& Disease Clearance.

\begin{tabular}{|c|c|c|c|c|c|c|c|}
\hline \multirow[t]{2}{*}{$\begin{array}{l}\text { Operative } \\
\text { Procedures }\end{array}$} & \multirow{2}{*}{$\begin{array}{c}\text { No of } \\
\text { patients } \\
\text { (n) }\end{array}$} & \multicolumn{2}{|c|}{$\begin{array}{c}\text { Follow up } \\
\text { At } 1^{\text {st }} \text { month }\end{array}$} & \multicolumn{2}{|c|}{$\begin{array}{c}\text { Follow up } \\
\text { At } 3^{\text {rd }} \text { month }\end{array}$} & \multicolumn{2}{|c|}{$\begin{array}{c}\text { Follow up } \\
\text { At } 6^{\text {th }} \text { month }\end{array}$} \\
\hline & & $\begin{array}{c}\text { Dry Ear } \\
\text { (n) }\end{array}$ & $\begin{array}{c}\text { Wet Ear } \\
\text { (n) }\end{array}$ & $\begin{array}{c}\text { Dry Ear } \\
\text { (n) }\end{array}$ & $\begin{array}{c}\text { Wet Ear } \\
\text { (n) }\end{array}$ & $\begin{array}{c}\text { Dry Ear } \\
\text { (n) }\end{array}$ & $\begin{array}{c}\text { Wet Ear } \\
\text { (n) }\end{array}$ \\
\hline $\begin{array}{l}\text { CWU with Type I } \\
\text { Tympanoplasty }\end{array}$ & 5 & 4 & 1 & 4 & 1 & 4 & 1 \\
\hline $\begin{array}{l}\text { CWU with Type II } \\
\text { Tympanoplasty }\end{array}$ & 10 & 9 & 1 & 9 & 1 & 10 & 0 \\
\hline $\begin{array}{c}\text { CWU with Type III } \\
\text { Tympanoplasty }\end{array}$ & 11 & 9 & 2 & 10 & 1 & 10 & 1 \\
\hline $\begin{array}{l}\text { CWUwith Type IV } \\
\text { Tympanoplasty }\end{array}$ & 2 & 1 & 1 & 1 & 1 & 1 & 1 \\
\hline $\begin{array}{l}\text { CWD with Type II } \\
\text { Tympanoplasty }\end{array}$ & 12 & 11 & 1 & 12 & 0 & 12 & 0 \\
\hline $\begin{array}{c}\text { CWD with Type III } \\
\text { Tympanoplasty }\end{array}$ & 7 & 6 & 1 & 6 & 1 & 7 & 0 \\
\hline $\begin{array}{c}\text { CWD with Type IV } \\
\text { Tympanoplasty }\end{array}$ & 3 & 2 & 1 & 2 & 1 & 2 & 1 \\
\hline
\end{tabular}

CWU - Canal Wall Up Procedures

CWD - Canal wall Down Procedures

In our study, Canal Wall Down Procedures (Modified radical mastoidectomy with Tympanoplasty) had a good successrate in disease clearance when compared with Canal Wall Up Procedures (Cortical Mastoidectomy/Atticotomy with Tympanoplasty). 
Table-2: Operative Procedures \& Hearing Status.

\begin{tabular}{|c|c|c|c|c|c|c|c|}
\hline \multirow{2}{*}{$\begin{array}{l}\text { Operative } \\
\text { Procedures }\end{array}$} & \multirow{2}{*}{$\begin{array}{c}\text { No of } \\
\text { patients } \\
\text { (n) }\end{array}$} & \multicolumn{2}{|c|}{$\begin{array}{c}\text { Follow up } \\
\text { At } 1^{\text {st }} \text { month }\end{array}$} & \multicolumn{2}{|c|}{$\begin{array}{c}\text { Follow up } \\
\text { At } 3^{\text {rd }} \text { month }\end{array}$} & \multicolumn{2}{|c|}{$\begin{array}{c}\text { Follow up } \\
\text { At } 6^{\text {th }} \text { month }\end{array}$} \\
\hline & & $\begin{array}{c}\text { Improve } \\
\text { (n) }\end{array}$ & $\begin{array}{c}\text { No } \\
\text { Improve } \\
\text { (n) }\end{array}$ & $\begin{array}{c}\text { Improve } \\
\text { (n) }\end{array}$ & $\begin{array}{c}\text { No } \\
\text { Improve } \\
\text { (n) }\end{array}$ & $\begin{array}{c}\text { Improve } \\
\text { (n) }\end{array}$ & $\begin{array}{c}\text { No } \\
\text { Improve } \\
\text { (n) }\end{array}$ \\
\hline $\begin{array}{l}\text { CWU with Type I } \\
\text { Tympanoplasty }\end{array}$ & 5 & 4 & 1 & 4 & 1 & 4 & 1 \\
\hline $\begin{array}{l}\text { CWU with Type II } \\
\text { Tympanoplasty }\end{array}$ & 10 & 9 & 1 & 9 & 1 & 10 & 0 \\
\hline $\begin{array}{l}\text { CWU with Type III } \\
\text { Tympanoplasty }\end{array}$ & 11 & 7 & 4 & 8 & 3 & 8 & 3 \\
\hline $\begin{array}{l}\text { CWUwith Type } \\
\text { IVTympanoplasty }\end{array}$ & 2 & 1 & 1 & 1 & 1 & 1 & 1 \\
\hline $\begin{array}{l}\text { CWD with Type II } \\
\text { Tympanoplasty }\end{array}$ & 12 & 10 & 2 & 12 & 0 & 12 & 0 \\
\hline $\begin{array}{l}\text { CWD with Type III } \\
\text { Tympanoplasty }\end{array}$ & 7 & 5 & 2 & 5 & 2 & 5 & 2 \\
\hline $\begin{array}{c}\text { CWD with Type IV } \\
\text { Tympanoplasty }\end{array}$ & 3 & 1 & 2 & 1 & 2 & 2 & 1 \\
\hline
\end{tabular}

CWU - Canal Wall Up Procedures

CWD - Canal wall Down Procedures

In our study, irrespective of canal wall up (or) canal wall down procedures, Type II Tympanoplasty show better results of hearing improvement when compared to other surgical procedures.

Table-3: Pre operative $\&$ post operative hearing status.

\begin{tabular}{|c|c|c|}
\hline Hearing Loss & $\begin{array}{c}\text { No. of Patients } \\
\text { (Pre Operative) }\end{array}$ & $\begin{array}{c}\text { No of Patients } \\
\text { (Post operative }-6^{\text {th }} \text { month) }\end{array}$ \\
\hline Normal & 0 & 4 \\
\hline Mild CHL & 5 & 32 \\
\hline Moderate CHL & 28 & 4 \\
\hline Moderately Severe CHL & 14 & 2 \\
\hline Severe CHL & 3 & 8 \\
\hline
\end{tabular}

In our study, pure tone audiometry was done in every patients at $1^{\mathrm{s}}, 3^{\text {rd }} \& 6^{\text {th }}$ months follow up, and significant hearing improvement found in $84 \%$ (42cases) patients. Out of 5(10\%) patients who had mild CHL pre-operatively, 4 ( $8 \%$ ) patient show improvement to normal hearing \& $1(2 \%)$ patient shows no improvement.

Out of $28(56 \%)$ patients who had moderate CHL pre-operatively, $26(52 \%)$ patient show improvement to mild CHL \& 2(4\%) patient shows no improvement. Out of 14(28\%) patients who had moderate severe CHL pre-operatively, 5 (10\%) patient show improvement to mild CHL, 6(12\%) patients show improvement to moderate CHL \& $3(6 \%)$ patient shows no improvement.

Out of 3(6\%) patients who had severe CHL pre-operatively, $1(2 \%)$ patient show improvement to moderate severe CHL \& 2(4\%) patient shows no improvement. 


\section{Discussion}

Demographic Distribution- In this study, it is found that maximum number of patients were in the age group of 21-30years (38\%) followed by 11-20 years age group $(32 \%)$. There were a small number of patients from pediatric age group (4\%).

So, inference can be drawn that number of patients with Chronic suppurative otitis media- atticoantral type begin to reduce after the age group of 30 . A. Sengutha et $\mathrm{al}$, found that maximum number of patients were in the age group of $11-20$ years (37.5\%) followed by $21-30$ years $(35 \%)[10]$.

Male and female ratio is approximately 2:1 in the present study and it correlates with other studies in this aspect. N.K. Chadha et al (2006) reported a male: female ratio of 2.2: 1[11]. D.S. Grewal et al (2003) shows a clear male predominance of 2.3: 1[12].

It has been found that $68 \%$ of patients in our series belong to lower socioeconomic class (family income $<=$ 1500 rupees / month), $24 \%$ belong to lower middle class (income between 1500 - 6000rupees). As people from lower classes live in crowded rooms with poor and unhygienic living conditions, giving rise to chronic ear problems and it is further compounded by pond bathing.

A. senguttha et al, found that $60 \%$ of patients in their study were lower socioeconomic class group (family income $<=1500$ rupees / month), where $35 \%$ belong to lower middle class group (income between $1500-6000$ rupees) [10].

All the patients had ear discharge \& hard of hearing $(100 \%)$ followed by ear itching (26\%), tinnitus $(10 \%)$, ear pain (6\%) and giddiness (4\%) in this study. D.S.Grewal et al found otorrhea in all patients $100 \%$ in his study [12]. M. Ajalloueyan et al found Ottorhea in $69 \%$, hard of hearing in $75 \%$ in his study among 72 patients [13]. In our study, out of 50 patients, 41 patients $(82 \%)$ has cholesteatoma followed by posterosuperior retraction pocket in 19 patients (38\%), attic retraction in 16 patients (32\%), attic perforation in 6 patients $(12 \%)$ and granulation tissue in 17 patients $(34 \%)$.

M. Ajalloueyan et al, among 72 patients, he found attic cholesteatoma in $32 \%$, and the remaining cholesteatoma originated from mesotympanum in $68 \%$. All patients had perforated tympanic membrane or attic retraction [13].
Preoperative Audiometry- In this present study, regarding the hearing assessment, in preoperative audiometry $10 \%$ (5cases) had mild hearing loss, $28 \%$ (56 cases) had moderate hearing loss, $14 \%$ ( 7 cases) had moderate severe hearing loss \& 6\% (3cases) presented with severe hearing loss. A. Sengutha et al, in his prospective study among 40 patients, reported regarding the hearing assessment, in preoperative audiometry $30 \%$ (12 cases) had mild hearing loss, $57.5 \%$ (23 cases) had moderate hearing loss, $12.5 \%$ ( 5 cases) had moderate severe hearing loss[10].

Preoperative Imaging Studies- In our study, Out of 50 patients, all the patients $(100 \%) \mathrm{X}$-ray shows sclerosed mastoid air cells. Out of which $15(30 \%)$ patients shows presence of Cholesteatoma and 7 (14\%) shows presence of cavity. In our study, as a part of investigation to all patients we had taken HRCT- Temporal bone. We found erosion and destruction of the lateral attic wall i. escutum in 5 patients $(10 \%)$, widening of the aditus and antrum as the destruction extends into antrum 11 patients $(22 \%)$, displacement of ossicles 16 patients (32\%), destruction of ossicles 27 patients (54\%), fistula formation with lateral semicircular canal in 1 patient (2\%), destruction of mastoid (Automastoidectomy) in 7 patients (14\%), erosion and sagging of the external canal roof in 3 patients $(6 \%)$.

Intraoperative- All cases, surgery was done through post aural route, canal wall down mastoidectomy with tympanoplasty was done in 22 cases $(44 \%)$ in whom there was extensive cholesteatoma. $28(56 \%)$ patients presented with limited disease and cortical mastoidectomy with tympanoplasty was done for those patients. Grafting was done with temporalis fasciafree graft in all cases $(100 \%)$.

All the seven patients with automastoidectomy and 1 patient with lateral semicircular canal fistula undergone modified radical mastoidecomy with tympanoplasty. A. Sengutha et al found that 25 cases $(62.5 \%)$ in whom there was extensive cholesteatoma, aural polyps, facial paralysis and intracranial complications. About $5(12.5 \%)$ patients presented with limited disease and cortical mastoidectomy and tympanoplasty was done for those patients. Grafting was done with temporalis fasciafree graft in 17 cases (42.5\%)[10].

Advantage of canal wall down mastoidectomy is that it offers excellent control of cholesteatoma. The disadvantage is that it creates a cavity that is more prone to infections and the patient is required to take 
precautions to keep it dry. Advantage of canal wall up mastoidectomy is that the basic normal anatomy of middle era is maintained and patient need not take extra precaution to keep the ear dry. Disadvantage is that, there is higher chance of recurrence of cholesteatoma. Regular follow up is required and patient may require a second look surgery. If patient has extensive cholesteatoma or patient wishes to avoid future operations or unable to return to follow up in future, then canal wall down procedure is safer and preferred.

Postoperative Audiometry- In our study, pure tone audiometry was done in every patients at $1 \mathrm{st}$, $3 \mathrm{rd} \& 6^{\text {th }}$ months follow up, and significant hearing improvement found in $84 \%$ (42cases) patients. Out of $5(10 \%)$ patients who had mild CHL pre-operatively, $4(8 \%)$ patient show improvement to normal hearing \& $1(2 \%)$ patient shows no improvement.

Out of $28(56 \%)$ patients who had moderate CHL preoperatively, $26(52 \%)$ patient show improvement to mild CHL \& 2(4\%) patient shows no improvement. Out of $14(28 \%)$ patients who had moderate severe CHL preoperatively, $5(10 \%)$ patient show improvement to mild CHL, 6(12\%) patients show improvement to moderate CHL \& 3(6\%) patient shows no improvement. Out of $3(6 \%)$ patients who had severe CHL pre-operatively, 1 (2\%) patient show improvement to moderate severe CHL \& 2(4\%) patient shows no improvement. Improvement of hearing attributed to tympanoplasty and ossiculoplasty.

Preciado DA et al (1999) stated that first, the malleus and incus in middle ear cholesteatoma maybe decayed and they should be removed to prevent recurrence of cholesteatoma. Second, it is hard to explore the anterior attic recess totally even if the lateral wall of attic is removed without removal of malleus and incusand also agreed that hearing can be improved and remain stable after type 3 tympanoplasty if the suprastapedial structures were intact [14]. M. Ajalloueyan et al, showed $30(42 \%)$ patients who underwent CWD mastoidectomy had a hearing level of $40 \mathrm{db}$ or better, and $39(54 \%)$ had a hearing level of $60 \mathrm{db}$ or better [13].

Recurrence of Cholesteatoma- In our study, no patient developed any intra-operative andpost-operative complications in follow up period. In different studies, recurrent cholesteatoma was found in $5-13 \%$ cases. Sheeley and Robbins reported that the rate was 5\% whereas Glassock reported that the rate was $14 \%$ [15]. Nyrop and Bonding's 10 year follow up, 70\% of patients needed second look and open cavity procedures[16]. Abramson et al (1977) reported patients treated for cholesteatoma withattico-antrostomy show a lower rate of recurrence rate of $17 \%$ where intact canal wall mastoidectomy shows 35\%[17]. Glassock (1977) reported that the choleateatoma recurrence rate of closecavity procedure was $14 \%$ [15].

Austin DF (1989) reported that rate of recurrence of cholesteatoma was $4 \%$ for the Canal wall down technique and $39 \%$ in intact canal wall technique [2]. Kapur TR et al (1997) detected 26.5\% failures (recurrence), $47.5 \%$ of which were due to attic retraction pocket, and $10 \%$ of which are due to residual cholesteatoma. The cholesteatoma recurrence rate in their patients with less than 10 years of follow up was $8.8 \%$, significantly lower than the rate in patients with more than 10 years of follow up[8].

\section{Conclusion}

Our study was undertaken to analyze the treatment outcome in terms of disease clearance and hearing statusand to find out the best surgical proceduresfor the treatment of chronic suppurative otitis media- attico antral type. In our study, we concluded that Canal wall down procedures shows good result ( $\mathrm{P}$ value is less than 0.01 ) thus proving to be statistically significant than canal wall up procedures in terms of disease clearance and Type II tympanoplasty shows good result ( $\mathrm{P}$ value is less than 0.01) thus proving to be statistically significant than other types of tympanoplasty in terms of hearing improvement.

\section{Why this study adds to existing knowledge?}

In conclusion, currently, single stage CWD tympanoplasty is still a clinically effective and cost-effective approach in treating acquired cholesteatoma for better disease clearance and hearing outcome.

Funding: Nil, Conflict of interest: Nil Permission from IRB: Yes

\section{References}

1. Monasta L, Ronfani L, Marchetti F, et al. Burden of disease caused by otitis media: systematic review and global estimates. PLoS One. 2012;7(4):e36226. doi: 10. 1371/journal.pone.0036226. Epub 2012 Apr 30.

2. Austin DF. Single-stage surgery for cholesteatoma: an actuarial analysis.Am J Otol. 1989Nov;10(6):419-25.

3. Dodson EE, Hashisaki GT, Hobgood TC, et al. Intact canal wall mastoidectomy with tympanoplasty for cholesteatoma in children. Laryngoscope. 1998 Jul; 108 (7) : 977-83. 
4. Sheehy JL, Shelton C. Tympanoplasty: to stage or not to stage. Otolaryngol Head Neck Surg. 1991 Mar;104 (3) : 399-407. DOI: 10.1177/019459989110400320

5. Portmann M,Portmann D. Tympanoplasty and other operations for combined indications, In: Portmann M, Portmann D, eds. Otologic surgery: manual of otosurgical techniques. London: Singular Publishing Groups, Inc.; 1998: 136-139.

6. Tarabichi M. Endoscopic management of cholesteatoma: long-term results. Otolaryngol Head Neck Surg. 2000 Jun; 122 (6): 874-81. DOI:10.1016/ S0194- 59980070017-9

7. Ji Heui Kim, Seung Hyo Choi, Jong Woo Chung. Clinical results of Atticoantrostomy with attic reconstruction or attic obliteration for patients with an attic cholesteatoma. Clinical and Experimental Otorhinolaryngology. Vol 2, No.1:39-43, March 2009.

8. Kapur TR, Jayarmachandran S. Management of acquired cholesteatoma of the middle ear and mastoid by combined approach tympanoplasty: a long-term view. Clin Otolaryngol. 1997;22:57-61

9. Glasscock- Shambaugh- Surgery of the Ear- Michael

E. Glasscock et al $-5^{\text {th }}$ ed.

10. Arunabha Sengupta, Tarique Anwar, Debasish Ghosh, Bijan Basak. A study of surgical management of chronic suppurative otitis media with cholesteatoma and its outcome. Indian J Otolaryngol Head Neck Surg (April-June 2010 ) 62 (2): 171- 176

11. N K Chadha, A Jardine, D Owens, S Gillett, P J Robinson, A R Maw. A multivariate analysis of the factors predicting hearing outcome after surgery for cholesteatoma in children. The Journal of Laryngology \& Otology (2006), Volume 120, Issue 11 November 2006, pp. 908-913https://doi.org/10.1017/ S00222151 06002179

12. D.S. Grewal, Bachi T. Hathiram, Alok V. Mohorikar, Santhosh Davis, T. Rajeevan. Retraction Pocket in chronic suppurative otitis media- our experience. Indian Journal of Otolaryngology and Head and Neck Surgery.Vol55, No 2, April - June 2003

13.Ajalloueyan M. Experience with surgical management of cholesteatomas. Arch Otolaryngol Head Neck Surg. 2006 Sep; 132(9): 931-3. DOI:10.1001/ archotol. 132. 9.931

14. Preciado DA, Levine SC. A review of type 3 tympanoplasty. Otolaryngol Clin North Am. 1999 Jun; 32 (3): 401-11.

15. Glasscock ME 3rd. Results in cholesteatoma surgery. Paper presented at the First International Conference on Cholesteatoma, Birmingham, Alabama; 1977.

16. Nyrop M, Bonding P. Achievement of stable ears in cholesteatoma surgery: long-term results of three surgical techniques. Paper presented at the Forth International Conference on cholesteatoma and Mastoid Surgery. Niigata, Japan; 1993.

17. Abramson M, Lachenbruch PA, Press BH, et al. Results of conservative surgery for middle ear cholesteatoma. Laryngoscope. 1977 Aug; 87 (8): 12817. DOI: 10. 1288/00005537-197708000-00008

\section{How to cite this article?}

Ganesh Bala Arivazhagan, Sriram Govindaraj, Ganesh Babu, Harishvel V. Prospective study of treatment outcome in chronic suppurative otitis media (Attico- antral Disease). Trop J Ophthalmol Otolaryngol.2019; 4(1)

:19-25.doi:10.17511/jooo.2019.i01.04 